\title{
Preserving and Transmitting the Teachings of the Tharigah ‘Alawiyyah: Diasporic Ba 'Alawi Female Preachers in Contemporary Indonesia
}

\section{Fatimah Husein ${ }^{1}$}

State Islamic University Sunan Kalijaga Yogyakarta-Indonesia

\begin{abstract}
Within academic discussions of Indonesia's Hadhrami diaspora, women's voices have often escaped scholarly attention. This paper focuses on the changing roles of three contemporary Indonesian Ba 'Alawi female preachers, in Jakarta, Surabaya and Solo, with regard to their endeavors in preserving and transmitting the teachings of the Thariqah 'Alawiyyah, a Sufi path that is traditionally reserved for men and which was established by the founding ancestor of the Ba 'Alawi, a descendant of the Prophet Muhammad named Muhammad b. 'Ali 'Alawi (d. 1255). While many important studies focus on the Hadhrami diaspora in Southeast Asia, and particularly on the role of male religious authorities, there is a dearth of research that takes the role of female actors seriously. This article presents a more complex picture of female $\mathrm{Ba}$ 'Alawi religious teachers, highlighting similarities between them, but also the differences. It argues that the intellectual legacies, spiritual engagements and genealogical connections that these female preachers enjoy have enabled them also to assume the roles of preservers and transmitters of the teachings of the thariqah. In doing so, they inform the dynamics of religious transmission spearheaded by Hadhramis in Indonesia today.
\end{abstract}

\footnotetext{
${ }^{1}$ An earlier version of this article was presented at the Workshop on "Us and Them: Diasporas for Others in the Indian Ocean," Martin Luther University, Halle, Germany, 16-18 September 2019. I wish to thank Iain Walker and Martin Slama for their helpful comments. I also thank two anonymous reviewers for their feedback on my draft, and extend my gratitude to all my interlocutors in Jakarta, Surabaya, and Solo that made this research possible in the first place.
}

(C) Fatimah Husein. This is an Open Access article distributed under the terms of the Creative Commons License CC BY NC SA, which permits users to share, use, and remix the material provided they give proper attribution, the use is noncommercial, and any remixes/transformations of the work are shared under the same license as the original. 


\section{Introduction: A Personal Account}

Being of Hadhrami descent myself, I have never thought that I would study my own community and traditions. How could I? During my childhood in Pasar Kliwon, a neighborhood in Solo, Central Java, being an "Arab" felt more like a curse than a blessing. I spent my twelve years of primary education at a school that was mostly attended by girls of Hadhrami descent, limiting my social interactions. My parents did not allow their children, especially the girls, to go to other schools because they saw them as "inappropriate." During my primary school years, I was consistently in the top two or three students in my class, which entitled me to go to the best high school in town. However, my parents would not allow me to attend.

In my neighborhood, local Javanese children often mocked us, singing "encik gogik madukoro silit pitik dilatono" ("lick chicken butt, you Arab!"). I was puzzled as to why they were so mean to us, even though we had no issues with them. Did we, the "Arabs,"2 bear very distinctive characteristics and identities that separated us from the locals? Were we seen as inherently incapable of adapting ourselves to the local cultures and traditions? Did they not know that our grandfathers held an "esteemed position" as Islamic educators in our community? This situation worsened after riots occurred against Hadhrami descendants in Solo in the 1980s.

Only later I realized that my community and the broader Hadhrami diasporic communities in Indonesia have received scholarly interest. Accounts of their country of origin, cultural and religious traditions and their political aspirations have been the focus of much research. A critical question that informs research on the Hadhrami diaspora, including the Hadhrami communities in Indonesia, relates to whether they assimilate to the host societies, or if their distinct identities are maintained, ${ }^{3}$ creolized, ${ }^{4}$ or adapted and manipulated. ${ }^{5}$

Indonesia's Hadhrami diaspora is divided into two main categories, namely the $\mathrm{Ba}$ 'Alawi (literally "the children of 'Alawi"), descendants of the Prophet Muhammad (sada,

\footnotetext{
${ }^{2}$ The term "Arab" is often used to refer to Indonesians of Hadhrami descent.

${ }^{3}$ Ahmed Ibrahim Abushouk and Hasan Ahmed, "Introduction," in The Hadhrami Diaspora in Southeast Asia: Identity maintenance or assimilations?, eds. Ahmed Ibrahim Abushouk and Hasan Ahmed (Leiden: Brill, 2009), 1-15; Natalie Mobini-Kesheh, The Hadrami Awakening: Community and identity in the Netherlands East Indies, 1900-1942 (New York: Cornell Southeast Asia Program Publications, 1999); Martin Slama, "Marriage as crisis: Revisiting a major dispute among Hadhramis in Indonesia," The Cambridge Journal of Anthropology, 32, 2 (2014), 65-80.

${ }^{4}$ Engseng Ho, The Graves of Tarim: Genealogy and mobility across the Indian Ocean (Berkeley: University of California Press, 2006); Sumit Mandal, Becoming Arab: Creole histories and modern identity in the Malay world (Cambridge: Cambridge University Press 2018).

${ }^{5}$ Ismail Fajrie Alatas, "The Ba 'Alawi in the interstices of the nation.” Die Welt des Islams, 51, 1 (2011), 45-74.
} 
sing. sayyid, feminine sing. sayyidah); and the masya'ikh (sing. syeikh, feminine sing. syeikhah) or non-sada. ${ }^{6}$ The Ba "Alawi "form the religious elite in the Hadhramaut" and occupy prominent positions in Indonesian Islam as well. ${ }^{7}$

The field of Hadhrami studies can be divided into two research traditions, one that revolves around the paradigm of diaspora studies, and another that is occupied with Islamic networks in the Indian Ocean. ${ }^{8}$ Boxberger focuses on important aspects of social and religious life of the Hadhramis between the 1880s and the 1930s, from the perspective of different groups within the society. ${ }^{9}$ She discusses how the practice of emigration throughout the Indian Ocean region had shaped Hadhrami identity and cultures. Walker's works are also diaspora-focused. ${ }^{10}$ In his research on Comorian Hadhramis, for example, he examines the similarities and the differences of Zanzibaris of Hadhrami origin and Zanzibaris of Comorian origin in their relationships with the homeland, which have differentially shaped their practices and identities. ${ }^{11}$ In the same paradigm, Freitag questions the role of Hadhramaut as the religious center for the Indian Ocean in the late $19^{\text {th }}$ and early $20^{\text {th }}$ centuries. ${ }^{12}$ She argues that by the $19^{\text {th }}$ century, it had lost its intellectual role within the wider Shafi' $i$ network of 'ulama in the northwestern Indian Ocean. On the other hand, studies that focus on the Islamic networks in the Indian Ocean are exemplified by Anne Bang and Nico Kaptein. Bang's thorough study on the scholarly exchange of ideas between Hadhramaut and the East African Coast centers on the life of Ahmad b. Abi Bakar b. Sumayt (d. 1925), ${ }^{13}$ whereas Kaptein delves into the life of Sayyid 'Utsman (d.

\footnotetext{
${ }^{6}$ For the discussion on hierarchies, see: Mobini-Kesheh, The Hadhrami Awakening, 24-26. In the Indonesian context, the category of masya' $i k h$ has been used to include other non-sada classes. Even though on the local level, for example in the Arab quarter of Solo, some masya' $i k h$ communities are aware of other categories such as qaba'il, generally they are referred to as non-sada or masya'ikh.

${ }^{7}$ Slama, "Marriage as crisis," 68; Alatas, "The Ba "Alawi," 47.

${ }^{8}$ There are studies that combine both approaches. See, for example: Ho, The Graves of Tarim; Ismail Fajrie Alatas, "The poetics of pilgrimage: assembling contemporary Indonesian pilgrimage to Hadramawt, Yemen," Comparative Studies in Society and History, 58, 3 (2016), 607-635. See also: Iain Walker and Martin Slama, "The Indian Ocean as diasporic space: A conceptual introduction," Journal of Indian Ocean World Studies, 4, 2 (2021), 76-90.

${ }^{9}$ Linda Boxberger, On the Edge of Empire: Hadhramawt, Emigration, and the Indian Ocean, 1880s-1930s (Albany: State University of New York Press, 2002).

${ }^{10}$ Iain Walker, "Hadramis, Shimalis and Muwalladin: Negotiating cosmopolitan identities between the Swahili coast and southern Yemen," Journal of Eastern African Studies 2, 1 (2008), 44-59; Iain Walker, "Hybridity, belonging, and mobilities: The intercontinental peripatetics of a transnational community," Population, Space and Place, 17 (2011), 167178; Iain Walker, "Comorians and Hadramis in the western Indian Ocean: Diasporic practices in a comparative context," Journal of Social Dynamics, 38, 3 (2012), 435-453; Iain Walker, "The Hadrami diaspora: A "diaspora for others" in the Indian Ocean," Journal of Indian Ocean World Studies, 4, 2 (2021), 188-210.

${ }^{11}$ Walker, "Comorians and Hadramis," 435-53.

${ }^{12}$ Ulrike Freitag, "Hadhramaut: A religious centre for the Indian Ocean in the late 19th and early $20^{\text {th }}$ centuries?," Studia Islamica, 89 (1999), 165-183.

${ }^{13}$ Anne K. Bang, Sufis and Scholars of the Sea: Family networks in East Africa, 1860-1925 (London: RoutledgeCurzon, 2003).
} 
1914), who spent some 20 years living and studying in Mecca and Hadhramaut, and had a long career teaching and preaching among Muslims in the Netherlands East Indies. ${ }^{14}$ Whereas most studies on Hadhrami women revolve around the paradigm of diaspora studies, my paper focuses on contemporary Indonesian Ba 'Alawi female preachers to show how they have become an integral part of the evolving Islamic networks in the Indian Ocean world, which remains relatively understudied.

There have been several works that focus on Hadhrami women in Indonesia. Slama's study of the agency of Hadhrami women, who live in the Indonesian cities of Jakarta, Yogyakarta, and on the island of Sulawesi, emphasizes their translocal networks through an Islamic organisation called Al-Khairaat by paying particular attention to their activities in the economic, social and educational sectors. ${ }^{15}$ The studies by Vera and Seise focus on different aspects of Hadhrami women's activities. Vera delves into the issue of $k a f a$ 'ah (equality in marriage) and the challenges faced by Ba 'Alawi women in Solo, Central Java, in marrying men of non-Ba 'Alawi descent, ${ }^{16}$ whereas Seise examines the participation of syarifah in female-only maulids (celebration of Prophet Muhammad's birthday) in Palembang, South Sumatra. ${ }^{17}$ Both articles contribute to the understanding of the gender dynamics in Indonesia's contemporary Hadhrami diaspora. Abaza's work on the new dakwah (proselytization) style in Jakarta examines gentrification and religious habitus among middle-class urbanities by focusing on majelis taklim (religious studies groups) that are mainly run by women. ${ }^{18}$ Related to this, Nisa discusses two Ba 'Alawi female preachers and their roles in the development of dakwah on the Jakartan preaching stage, which was mostly dominated by male preachers. ${ }^{19}$ By showing this new visibility of $\mathrm{Ba}$ 'Alawi women in Indonesian public Islam, both authors have located the works of these women preachers in the paradigm of the study of Indonesian Islam.

My research seeks to contribute to the study of the Hadhrami diaspora in Indonesia, their Sufi networks, and Islamic developments in Indonesia more generally. It concentrates on recent developments among Indonesian Ba 'Alawi women preachers

\footnotetext{
${ }^{14}$ Nico Kaptein, Islam, Colonialism and the Modern Age in the Netherlands East Indies: A biography of Sayyid 'Uthman (1822-1914) (Leiden: Brill, 2014).

${ }^{15}$ Martin Slama, "Coming down to the shop': Trajectories of Hadhrami women into Indonesian public realms," The Asia Pacific Journal of Anthropology, 13, 4 (2012), 313-33.

${ }^{16}$ Nawiroh Vera, "Komunikasi perempuan etnik Arab terkait tradisi pernasaban dalam perspektif feminisme Islami: Kajian etnografi kritis tentang perkawinan se-kufu di kalangan perempuan Arab di Kota Solo" (Unpublished Ph.D. diss., Padjajaran University, 2018).

${ }^{17}$ Claudia Seise, "Women remembering the Prophet's birthday: Maulid celebrations and religious emotions among the Alawiyin community in Palembang, Indonesia," Austrian Journal of South-East Asian Studies, 11, 2 (2018), 217-230.

${ }^{18}$ Mona Abaza, "Markets of faith: Jakartan Da'wa and Islamic gentrification." Archipel 67 (2004), 173-202.

${ }^{19}$ Eva F. Nisa, "Female voices on Jakarta's da'wa stage," Review of Indonesian and Malaysian Affairs, 46, 1 (2012), 55-81.
} 
(asatidzah, sing. ustadzah) and their dakwah activities attempting to preserve and transmit the teachings of Thariqah 'Alawiyyah ("the Ba 'Alawi path"), a Sufi (Islamic mysticism) order established by Muhammad b. 'Ali 'Alawi (d. 1255) (discussed below). Three women preachers who reside in Jakarta, Surabaya and Solo, three major Indonesian cities with a strong Hadhrami presence, are examined to offer some grounded observations on how contemporary Indonesian $\mathrm{Ba}$ 'Alawi women assume a new role in helping to preserve and to transmit the teachings of the Thariqah 'Alawiyyah in the host country. ${ }^{20}$

I argue that their intellectual and spiritual engagements with Habib 'Umar b. Muhammad b. Hafidz (b. 1963), a respected Ba 'Alawi leader who established Dar alMustafa and Dar al-Zahra in Tarim (discussed below), Hababah Ummu Salim (Habib 'Umar b. Hafidz's wife), as well as their immersion with Ba 'Alawi traditions in Tarim, empower them also to become preservers and transmitters of the teachings of the Thariqah 'Alawiyyah. As I will show below, their participation in the transmission of Prophetic knowledge, observance of daily litanies, and maintenance of the connection to the ancestors conform to what is prescribed by the thariqah. I further argue that their combination of lineage, which genealogically aligns them with the Prophet Muhammad, and distinct moral practices prescribed by their teachers in Hadhramaut allow them to assume their new roles.

\section{Women's ACCESS to AND THEIR Role in RELigious EduCATION}

Asma Sayyed notes two opposing narratives available on Muslim women's access to, and subsequently role in, religious education. ${ }^{21}$ One view argues that Muslim women were oppressed throughout Islamic history, and thus had no access to religious education, while the other perceives them as having opportunities as exemplified by Prophet Muhammad's wife, 'Aisyah bt. Abu Bakar (d. 678). 'Aisyah bt. Abu Bakar is known as a prominent transmitter of Hadits, the deeds and sayings of the Prophet. Together with Ummu Salama (d. 680), she narrated approximately 2,400 Hadits, where she held the first authority. ${ }^{22}$ Indeed, these Hadits contain many moral teachings of the Prophet that later became the basis of Sufi values and practices.

The history of Islam also records Muslim women who became Sufis, chief among them Rabi'ah al-'Adawiyyah (d. 801), who was known for her ascetic life and who has

\footnotetext{
${ }^{20}$ The term "host country" is used here to refer to Indonesia.

${ }^{21}$ Asma Sayeed, Women and the Transmission of Religious Knowledge in Islam (Cambridge: Cambridge University Press, 2013), 2.

${ }^{22}$ Ibid., 25.
} 
inspired many other male and female Sufis. Even though early Islam also noted some other women Sufi figures, Silvers argues that "the sheer number of extant reports of men compared to women in the formative literature means that women are read as marginal to the development, transmission, and preservation of Sufi practices, knowledge, and teaching." "23 Some contemporary female scholars attempt to bring to our attention the teachings of female Sufis and to explore contemporary women's involvement and leadership in Sufism in different parts of the world. ${ }^{24}$

The opposing narratives of the roles of Muslim women in religious education and in the transmission of Sufism can also be observed in the Indonesian context. We find some strong female figures such as Rahmah El-Yunusiyah (d. 1969) who is one of the few initiators of Islamic schools for women in West Sumatra. The school, Sekolah Diniyah Putri, which she started in the early 1920s, still exists. Likewise, Siti Walidah (d. 1946), the wife of Ahmad Dahlan, the founder of the Muhammadiyah organization, formalized women's religious gatherings as Aisyiyah in 1917, which later became the female's wing of Muhammadiyah. Aisyiyah provides Islamic education for girls and women and continues to play an important role in voicing Muslim women's rights. Contemporary Indonesian Muslim women have taken these initiatives further, developing their roles in the public sphere, including in the religious, educational, and business sectors. ${ }^{25}$ While studies of the development of Sufism in Indonesia exist, accounts of women's roles as transmitters of Sufi knowledge and practices are rare. In her work on Sufism in Indonesia, Julia Howell, for example, presented a new development of "Sufi-inflected religious predication," also known as "urban Sufism," that is to be differentiated from the thariqahbased Sufism. ${ }^{26}$ She, however, does not specifically examine the role of women in the discourse.

\footnotetext{
${ }^{23}$ Laury Silvers, "Early pious, mystic Sufi women," in The Cambridge Companion to Sufism Online, ed. Llyod Redgeon, (Cambridge: Cambridge University Press, 2014), 25.

${ }^{24}$ Ibid., passim; Maria M. Dakake, “'Guest of the inmost heart': Conceptions of the Divine Beloved among early Sufi women," Comparative Islamic Studies, 3, 1 (2007), 72-97; Kelly Pemberton, "Women Pirs, saintly succession, and spiritual guidance in South Asian Sufism," The Muslim World, 96 (2006), 61-87; Silvia Bruzzi and Meron Zeleke, "Contested religious authority: Sufi women in Ethiopia and Eritrea," Journal of Religion in Africa, 45 (2015), 37-67; Codou Bop, "Roles and the position of women in Sufi brotherhoods in Senegal," Journal of the American Academy of Religion, 73, 4 (2005), 1099-119.

${ }^{25}$ See, for example: Nisa, "Female voices," 55-81; Slama, "Coming down to the shop," 313-33; Millie, Julian. 2011. "Islamic Preaching and Women's Spectatorship in West Java.' The Australian Journal of Anthropology 22: 151-69; Millie, Julian. 2011. 'Islamic Preaching and Women's Spectatorship in West Java.' The Australian Journal of Anthropology 22: 151-69; Marcoes, Lies. 1992. "The Female Preacher as a Mediator in Religion: A Case Study in Jakarta and West Java." In Women and Mediation in Indonesia, edited by S.T. van Bemmelen et al, 203-28. Leiden: KITLV Press.

${ }^{26}$ Julia Day Howell, "Introduction: Sufism and Ne-Sufism in Indonesia today," Review of Indonesian and Malaysian Affairs, 46, 2 (2012), 4.
} 
In the more specific context of Hadhrami communities, it is important to examine the roles of women in the religious realm. During the heyday of Hadhrami migration to the Netherlands East Indies in the late $19^{\text {th }}$ and early $20^{\text {th }}$ centuries, only a few Hadhrami women played a role as religious educators of the girls in the community. In the Arab quarter of Solo in the late 1940s, for example, Fatimah bt. Salim Abdat of the masya 'ikh community, known as Bu Fatimah Guru or Ms. Fatimah "the teacher," offered religious education for Hadhrami girls at her home. My mother recalls her days spent learning basic Islamic teachings, such as reading the Qur'an and ethics (akhlaq) at Fatimah's house. In addition, she and her Hadhrami friends also learned some general subjects, such as basic arithmetic, from Ustadzah 'Aisyah, a Sundanese woman married to Ahmad b. 'Abdullah Assegaf of $\mathrm{Ba}$ 'Alawi descent. Even though Al-Rabithah Al-'Alawiyyah, a Ba 'Alawi organisation that is active in dakwah and education, already existed in Solo at that time, it did not accept female students. ${ }^{27}$

When my female cousins went to study at the Diponegoro school in the early 1970s, almost all of their teachers were Ba 'Alawi men who were born in Hadhramaut, and there were no female teachers. Outside the formal school, they admitted that they learned a great deal of Islamic teachings and practices from their parents, especially mothers. It was the mothers who continued to involve their daughters in various home gatherings where the extended family read the Qasidah Al-Burdah (Eulogy of the mantle) of Imam Muhammad al-Bushiry (d. 1294) and the Manaqib (hagiography) of Syeikh Abdul Qodir al-Jailany (d. 1166), which provided them with valuable moral teachings. We see here the opposing narratives of the roles of Muslim women in religious education as stated by Asma Sayeed. ${ }^{28}$ Even though, as mentioned above, the role of Hadhrami women, Ba 'Alawi and non-Ba 'Alawi alike, as Islamic educators were very limited within the public sphere, they played a significant role in the private sphere. Before discussing how contemporary Ba 'Alawi women are changing this, it is important to discuss how the Thariqah 'Alawiyyah, which is an important signifier of their diaspora, was traditionally preserved.

\section{Preserving the ThariQah 'Alawiyyah}

The Thariqah 'Alawiyyah that shapes the identity of the Hadhrami community was established by Muhammad b. 'Ali Ba 'Alawi, also known as al-Faqih al-Muqaddam, the

\footnotetext{
${ }^{27}$ Al-Rabithah Al-'Alawiyyah that had been formed in Jakarta in 1927 opened a branch in Solo in 1928 (see: https://rabithahalawiyah.id/perihal/sejarah/). As the organization developed in Solo, it changed its name to Diponegoro, named after an important Indonesian national hero, in March 1966 and started to accept female students.

${ }^{28}$ Sayeed, Women and the Transmission.
} 
paramount jurist, who indirectly received the cloak of Sufi investiture (ilbas khirqat altasawwuf) from Syu'ayb Abu Madyan (d. 1197), the Sufi saint of Tlemcen in Morocco, through 'Abdullah al-Shalih al-Maghribi. ${ }^{29}$ Since the Thariqah 'Alawiyyah has been the subject of a variety of studies, I will only discuss it briefly here. ${ }^{30}$ Bang defined the thariqah as "a transmission of mystical knowledge in the genealogical chain, which then was infused with the Madyaniyya during the lifetime of al-Faqih al-Muqaddam." 31 Two salient features, therefore, characterize the thariqah: a genealogy of the Prophet Muhammad's family and a spiritual genealogy of Abu Madyan. ${ }^{32}$

The thariqah as it is practiced today consists of "a canon of saints, texts, rituals, special places, and genealogies" that has been institutionalized. ${ }^{33}$ To this, Alatas added another element, "the scholarly network in the form of iqd al-suhba (pledge of fellowship) binding people based on their adherence to the tariqa." ${ }^{34}$ The texts and rituals, which imitate the Prophetic piety prescribed by the pious ancestors of the sada, differentiate the thariqah from general Islamic teachings. At its earlier stage, the thariqah was restricted to the elites. However, 'Abdullah b. 'Alawi al-Haddad (d. 1720) reformed the thariqah so that it was a more accessible Sufi path that does not require formal initiation. Membership of the thariqah has been envisaged as participating in the transmission of Prophetic knowledge, daily worship, maintaining connections to the ancestors through practices like hadhrah (lit. hadhara, being present, a ritual of invoking the Prophet's spirit), and observing the daily litanies like the ratib. ${ }^{35}$

Ho further argued that the thariqah is "a malleable discourse that evolved over time." 36 This is proven, for example, within the Indonesian context where some Ba "Alawi scholars adapted and reconfigured their Sufi path to become, among other things, "a popular religious expression centered on scriptural Prophetic piety and devotion." 37 The Ba 'Alawi in Solo, for example, hold an annual haul, a commemoration of the death of Habib 'Ali b. Muhammad al-Habsyi (d. 1915 in Hadhramaut) every month of Rabiul Tsani. This event has also been used to commemorate the death of his son Habib 'Alwi b.

\footnotetext{
${ }^{29}$ Bang, Sufis and Scholars, 14; Ho, The Graves of Tarim, 41.

${ }^{30}$ See, among others: Bang, Sufis and Scholars; Alatas, "The Ba 'Alawi," 45-74; Alatas, "Pilgrimage and network formation," 298-324; Ho, The Graves of Tarim.

${ }^{31}$ Bang, Sufis and Scholars, 15-16.

${ }^{32}$ See also: Ismail Fajrie Alatas, "[al-]"Alawiyya (in Hadramawt)," The Encyclopedia of Islam: Three, eds., Gudrun Krämer, Roger Allen, and Kate Fleet (Leiden and Boston: Brill, 2010), 47; Ho, The Graves of Tarim, 55.

${ }^{33}$ Ho, The Graves of Tarim, 47.

${ }^{34}$ Alatas, "The Ba "Alawi," 47.

${ }^{35}$ Alatas, "[al-]"Alawiyya (in Hadramawt)," 49.

${ }^{36} \mathrm{Ho}$, The Graves of Tarim, 47.

${ }^{37}$ Alatas, "The Ba 'Alawi," 59.
} 
'Ali al-Habsyi (d. 1954 in Solo), and his grandchildren Habib Anis b. 'Alwi al-Habsyi (d. 2006 in Solo) and Habib Ahmad b. 'Alwi al-Habsyi (d. 2008 in Solo).

It is important to note how the haul supports the $\mathrm{Ba}$ 'Alawi in Solo in their identity maintenance. In particular, the event helps to remind the younger generation of the $\mathrm{Ba}$ 'Alawi of the great life of Habib 'Ali al-Habsyi and his descendants. In his reading of the manaqib of Habib 'Ali al-Habsyi at the haul in 2018, for example, Habib 'Umar b. Abu Bakar al-Muhdhor (d. 2020) accentuated the excellent moral practices lived by Habib 'Ali al-Habsyi, and the latter's message was directed at urging young people in the community to hold on to the Thariqah 'Alawiyyah. Furthermore, collective visits (ziyarah) to the tombs of Habib 'Alwi b. 'Ali al-Habsyi, Habib Anis b. 'Alwi al-Habsyi, and Habib Ahmad b. 'Alwi al-Habsyi during the haul underlines one of the central teachings of the thariqah, namely "the belief in the baraka embodied in famous holy men and scholars." 38 The ziyarah and the haul have therefore given special meaning to Ba 'Alawi in strengthening their identity.

Another approach to preserving the Thariqah 'Alawiyyah is through maintaining the genealogy and identity of the $\mathrm{Ba}$ 'Alawi, and marriage is naturally one of the most crucial components. As stated by Mobini-Kesheh, "upholding the status of the sayyids was an essential part of being Hadrami. Being Hadrami meant kissing sayyids' hands and upholding marriage restrictions." 39 We have learned from Hadhrami diasporic history how Ahmad Surkati, a religious scholar from Sudan who established the Al-Irsyad AlIslamiyyah organization in 1914, rejected the sada-masyai' $k h$ dualism and challenged the doctrine of kafa'ah (equality in marriage). ${ }^{40}$ This is very much in line with Syed Farid Alatas's statement that the locus of Hadhrami diasporic identity "was not so much language, but nasab (lineage), which formed the basis of a uniquely Hadhrami type of 'asabiyya." ${ }^{41}$ Even though Islam is a shared identity for Hadhrami and other Indonesians, this does not ease the marriage requirement for the $\mathrm{Ba}$ 'Alawi women.

This marriage restriction, however, does not apply to Indonesian Hadhrami males. Most, if not all, of them left their wives at home. Van den Berg explained:

\footnotetext{
${ }^{38}$ Bang, Sufis and Scholars, 22.

${ }^{39}$ Mobini-Kesheh, The Hadrami Awakening, 99.

${ }^{40}$ See: Ibid., 94-8; Ho, The Graves of Tarim, 173-81; Bang, Sufis and Scholars, 17; Vera, "Komunikasi perempuan," $33-6$.

${ }^{41}$ Syed Farid Alatas, "Hadhramaut and the Hadhrami diaspora: Problems in theoretical history," in Hadhrami Traders, Scholars and Statesmen in the Indian Ocean, 1750s-1960s, eds. Ulrike Freitag and William G. Glarence-Smith (Leiden, New York, Köln: Brill, 1997), 29.
} 
The wives always refused to accompany their husbands to go outside Hadhramaut. Even though according to Islamic law this rejection could dissolve their marriage, their husbands continued to take care of their wives in Hadhramaut. They, however, took second wives in their new homes. ${ }^{42}$

Taking Indonesian wives does not undermine their status of being a sayyid as their lineage is patrilineal. Moreover, these local wives would give birth to children, and would make sure that the latter embrace the cultures and traditions of their host country, and thus ensuring an easier acceptance by the local community. Ho called this "asymmetrical marriage exchanges" because, while on the one hand they allow themselves to marry local wives and do not want their children to experience a sense of displacement in the new home, they, on the other hand, try to preserve their diasporic identities as the $\mathrm{Ba}$ 'Alawi by forbidding their daughters to marry non-Ba 'Alawi. ${ }^{43}$

A more practical method of preserving the Thariqah 'Alawiyyah among the $\mathrm{Ba}$ 'Alawi is by sending their male children to the Hadhramaut to study. Although "the religious learning for which Hadhramaut had been famous in the preceding centuries went into decline in the 11th/18th century," which might have been caused by "political instability," as Freitag noted, the practice of sending youth to Hadhramaut continued, especially with the development of transportation technologies in the late $19^{\text {th }}$ century. ${ }^{44}$ Indonesian-born Hadhramis (muwalladin) went to the Hadhramaut to immerse them into the cultures and customs of their ancestors and to maintain relationships with the homeland. ${ }^{45}$ This diasporic strategy is not uniquely Indonesian. The Hadhrami community in Zanzibar, for example, has also had this tradition of sending their male children to Hadhramaut, not only to learn the language and Hadhrami values but also to be acquainted with "the value of money and the merits of hard work" as lived by the community. ${ }^{46}$

The above accounts indicate that it was the male side of the Ba 'Alawi community who came to the Indonesian archipelago and took the lead in preserving the Thariqah 'Alawiyyah. While they try to gain acceptance in the host country, the above accounts of haul and ziyarah in Solo, of maintaining the genealogy of the Ba 'Alawi through marriage

\footnotetext{
${ }^{42}$ L.W.C. van den. Berg, Orang Arab di Nusantara (Le Hadhramaut et les colonies Arabes dans l'archipel Indien). Trans. Rahayu Hidayat (Indonesian) (Depok: Komunitas Bambu, 2010), 85. Translation into English is mine.

${ }^{43}$ Ho, The Graves of Tarim, 187.

${ }^{44}$ Freitag, "Hadhramaut: A Religious Centre," 167.

${ }^{45}$ The term "homeland" here is used following the definition proposed by Iain Walker, referring to "a place of origin of a diasporic community, and not necessarily to a place where people are 'at home'." See: Walker, "Comorians and Hadramis," 438.

${ }^{46}$ Ibid., 442.
} 
restrictions for women, and of sending the male children to Hadhramaut, all show that "nurturing their diasporic consciousness" and ensuring the connection with the place called homeland was reserved to the male members of the family. ${ }^{47}$ Within the context of patrilineal society in Hadhramaut, it is clear that the thariqah is mostly a male affair. This, however, does not mean that there have been no Hadhrami female scholars, Sufis, saints, and members of the thariqah throughout the Hadhrami history. Boxberger discusses some of these pious women, such as Shaykha 'A'isha bt. Ahmad Ba Jamal and Shaykha Sultana bt. 'Ali al-Zubaydi (d. 1440), who are revered for their piety and whose tombs are still visited today. ${ }^{48}$ In addition, Alaydrus shares her experiences with some saintly women in Tarim who live a mystical life and practice the thariqah rituals. ${ }^{49}$

While it is true that in the hand of Muhammad b. 'Ali Ba 'Alawi, it "became organized, adopting the technical vocabulary of pathway (tariqa), appointment (tahkim), license (ijaza), mantle (khirqa), litany (dhikr), and so on," Ho also argued that this thariqah has evolved over time and adapted to different historical and cultural settings. ${ }^{50}$ Alatas further underlined that this thariqah never became "a fully institutionalised order." 51 This is emphasized by Knysh as well, who sees Sufism in contemporary Hadhramaut as "associated primarily with the informal network of groups of disciples aggregating around a reputed Sufi master" where relations between the teacher-disciples are less "formal or hierarchical." 52 In the next section I will show that Indonesian Ba 'Alawi women also play an important role in the preservation and transmission of the thariqah's teachings. The new practice of Indonesian $\mathrm{Ba}$ 'Alawi women of studying at Dar al-Zahra Islamic boarding school in Hadhramaut (discussed below) marks an important change in their role in the preservation and transmission of the thariqah.

\section{Sending Ba ‘Alawi Women to the Hadhramaut}

In 1993, Dar al-Mustafa, a boarding school for male pupils under the leadership of Habib 'Umar b. Hafidz was established in Tarim. He is known as the reviver of the "expressions of devotion to the members of the Ba "Alawi family," which were abolished by the

\footnotetext{
${ }^{47}$ Alatas, "The Ba 'Alawi," 45.

${ }^{48}$ Boxberger, On the Edge of Empire, 155;

${ }^{49}$ Halimah Alaydrus, Bidadari Bumi: 9 Kisah Wanita Salehah (Jakarta: Wafa Press, 2014).

${ }^{50}$ Ho, The Graves of Tarim, 41.

${ }^{51}$ Alatas, "[al-]"Alawiyya (in Hadramawt)," 47.

52 Alexander Knysh, "The Tariqa on a landcruiser: The resurgence of Sufism in Yemen," Middle East Journal, 55, 3 (2001), 400 .
} 
Socialist regime that ruled South Yemen from 1967 to $1990 .{ }^{53}$ Even though this boarding school is not specifically linked to the Thariqah 'Alawiyyah, Sufi literature is quite significant within the curriculum, and "in accord with the tenets of the tariqa al'alawiyya" Sufism is taught to the students of the school "primarily as morals and spiritual self-discipline. ${ }^{, 54}$ Its distinctive programs include learning and implementing the basics of suluk (taking a spiritual pathway to Allah), which is also an important element of the thariqah.

Due to the requests from many Muslim women, Dar al-Zahra was later established in 1998. It currently receives students from various ethnic groups and nationalities, who are taught by male and female teachers. Habib 'Umar b. Hafidz regularly teaches at this boarding school from behind the curtain and is projected on a TV screen for the female students to see. He teaches Siroh Nabawiyyah (the history of Prophet Muhammad). The figure of Hababah Nur bt. Muhammad al-Haddar (Habib Umar b. Hafidz's wife, known as Hababah Ummu Salim) is also important as she regularly teaches the students, both at the boarding school and at her own house. One main subject that she teaches is tasawwuf, primarily using the book Ar-Risalah Al-Mu'awanah (Treatise on Assistance) authored by Habib 'Abdullah b. 'Alawi al-Haddad. ${ }^{55}$ Some of Dar al-Zahra's students are even given the opportunity to stay at her house and help with the household, where they directly learn the Hababah's daily religious practices, in addition to their formal study. It is thus clear that even though the boarding school is not meant as a training ground for the disciples of the thariqah, the influence of Habib Umar b. Hafidz and Hababah Ummu Salim, coupled with the curriculum and the spiritual practices the students embody help shape them to become the preservers and transmitters of the thariqah's teachings. The frequent visits of Habib 'Umar b. Hafidz and Hababah Ummu Salim to Indonesia also strengthen this student-teacher relationship. Many female alumni of Dar al-Zahra, for example, are encouraged to accompany Hababah Ummu Salim when she delivers her dakwah in various Indonesian cities, especially Jakarta and Solo. This parallels the practices of the male disciples of Habib 'Umar b. Hafidz, who accompany him during his public sermons and lectures in the Hadhramaut. ${ }^{56}$

The following three ethnographic examples of Indonesian Ba 'Alawi women will examine their motives for studying in Hadhramaut and their roles upon returning from

\footnotetext{
53 Ibid., 408.

${ }^{54}$ Ibid., 410.

${ }^{55}$ Interview with Ustadzah Khodijah Assagaf in Surabaya, 11 November 2019.

${ }^{56}$ Knysh, "The Tariqa on a landcruiser," 406-7.
} 
their studies. These three examples represent different generations, and they differ with regard to the length of their studies in Hadhramaut and their motivations. The first, and best-known, is Ustadzah Halimah Usman Alaydrus, who was born in 1979 in Indramayu, West Java. ${ }^{57}$ Her family name indicates that she belongs to the Ba 'Alawi family. She is married to a sayyid named Ahmad al-Haddar and thus maintains her elite descent. As a child she was determined to go to a pesantren, an Islamic boarding school, and, therefore, with her father's encouragement, did not to go to formal schools. Her first training was at Pesantren Darul Lughah wad Da'wah in Bangil, East Java, a pesantren that was established in 1981 by Habib Hasan b. Ahmad Baharun (d. 1999) who was also from a Ba'Alawi family. She then continued her studies at Pesantren At-Tauhidiyah in Tegal (1995), and Pesantren Al-Anwar in Rembang (1996), both located in Central Java. In addition to her education at these pesantren she was later entrusted to teach at those same institutions. After several years of teaching, she continued her education in Hadhramaut. Though she yearned for a female role model in her Muslim faith that she could follow, her travel to Hadhramaut was only possible due to the company of her brother, who was also going there to study. Ustadzah Halimah stated that during her first year in Tarim there was no boarding school for women, and therefore she copied her brother's lessons from Dar al-Mustafa.$^{58}$ As soon as Dar al-Zahra opened she began her studies for the next four years (1998-2002).

Since returning to Indonesia, Ustadzah Halimah has been active as a preacher at various religious gathering sessions (pengajian), both in Indonesia and overseas. She often holds safari dakwah (a series of dakwah, which runs for several days) and daurah (lit. training, a short term pesantren) to teach a variety of different Islamic topics. She is an author of a variety of different books, including books on Muslim women and marriage counseling. In addition, she is quite active on social media, chiefly Instagram, Facebook, and even has her own YouTube channel.

The second figure is Ustadzah Khodijah Abdulqodir Hud Assegaf. Born in 1978, she received her primary education at Al-Khairiyah in Surabaya, which was established in 1895 under the leadership of Habib Muhammad bin Ahmad al-Muhdor. She then continued to At-Tarbiyah and Al-Irsyad, both also located in Surabaya. ${ }^{59}$ After completing

\footnotetext{
${ }^{57}$ Eva F. Nisa has discussed the roles of Ustadzah Syarifah Halimah Alaydrus and Ustadzah Syarifah Khadijah al-Junayd in Islamic preaching and in strengthening the position of other Ba 'Alawi female preachers in Indonesia. See: Nisa, "Female voices," 55-81.

${ }^{58}$ This information was taken from her personal blog: halimahalaydrus.blogspot.com.

${ }^{59}$ Her choice of studying at Al-Irsyad was interesting because the school is known for catering to the educational needs of non-sada Hadhramis. However, as she explained, she chose Al-Irsyad because it was only this school that provided a
} 
her formal education, she learned Arabic language at Lembaga Pengajaran Bahasa Arab Ampel Surabaya for two years. Then, with the encouragement of her uncle, Habib Husin b. Abdullah b. Muhammad Assegaf (d. 2019) of Gresik, East Java, she went to study at Dar al-Zahra in 2006.

Ustadzah Khodijah spent one and a half years in Tarim. She intended to stay longer to deepen her knowledge and experiences but had to go back to Indonesia due to her father's illness. Upon her return to Surabaya, she started a female pengajian at her house, which continued to grow due to the high demand within her own neighborhood. In our interview, she stated that ninety percent of her pengajian members are Ba 'Alawi females, while ten percent are other Muslim women. Unlike Ustadzah Halimah, Ustadzah Khodijah is not media- and tech-savvy, and mostly works offline.

While Ustadzah Halimah and Ustadzah Khodijah represent the older generation of Indonesian Ba 'Alawi women who studied in Hadhramaut, Ustadzah Syifa Muhsin alHaddad, born in Solo in 1995, exemplifies a younger generation. After completing primary school at Diponegoro in Solo, Ustadzah Syifa had no interest in continuing her education in high school, but rather was determined to continue her education at a pesantren. This inclination came from herself without any encouragement from her parents. Her love of religion and the Arabic language brought her to Pesantren Suniyyah Salafiyyah in Pasuruan, East Java, under the guidance of Ustadz Taufiq b. Abdul Qodir Assagaf (b. 1969). This pesantren has revived some traditional methods of learning from the Hadhramaut including rohah (lit. relax, meaning reading a variety of Islamic classical books together).

Ustadzah Syifa spent five years at this pesantren (2008-2013). Upon her return to Solo, she taught at Dipenogoro school, teaching junior and senior high school students. However, her longing to study in Hadhramaut did not cease. An opportunity came in 2017, when some of her female cousins went to Tarim; a good friend from Solo also enrolled in Dar al-Zahra, and she joined her. She continues to teach at Diponegoro high school, which is exclusively for girls, and chooses doing so as her dakwah strategy. She declined to deliver her dakwah publicly in the form of public pengajian as Ustadzah Halimah, because she believes that other teachers have filled that role. ${ }^{60}$ She also does not use social media as a means to convey her dakwah, which is rather unusual for an ustadzah of her generation. This, however, could be explained by her background, mentioned above,

separated high school education for male and female students. Interview with Ustadzah Khodijah in Surabaya, 11 November 2019.

${ }^{60}$ Interview with Ustadzah Syifa al-Haddad in Solo, 9 January 2020. 
especially her training at the traditional pesantren from an early age, which might have led her to have some reservations regarding the use of social media.

The three examples above underline an important point. It was the male members of the family who encouraged the two Ba 'Alawi women discussed first to study in Hadhramaut. In the case of Ustadzah Halimah it was her father who influenced her to go to Hadhramaut, while Ustadzah Khodijah was supported by her uncle, who is a very wellknown Ba 'Alawi ustadz in East Java. The case of Ustadzah Syifa was different as it was her own determination to go to the Hadhramaut. However, she argued that without her father's permission, this would not have been possible. These cases reflect two interesting realities. First, while in the past the men of the $\mathrm{Ba}$ 'Alawi community who came to the Netherlands East Indies sent their sons to the Hadhramaut, they now encourage and allow $\mathrm{Ba}$ 'Alawi women to study in the homeland. ${ }^{61}$ Second, with this opportunity to learn and to immerse themselves in the knowledge, cultures and values of the homeland, chiefly Sufi knowledge and practices, the female Ba 'Alawi community members assumed new roles as holders of religious authority. The following section describes these new roles.

\section{Changing Roles of Ba ‘Alawi Women}

For many years, $\mathrm{Ba}$ 'Alawi male graduates from Hadhramaut have spread their knowledge and practices by opening boarding schools and pengajians in their host societies. For example, after completing his two-year-study at Dar al-Mustafa in 1999, Ustadz 'Alwi b. 'Ali al-Habsyi (b. 1970) came back to Solo and developed Ma'had Al-Hidayah. In addition to teaching the Islamic foundational texts, the Qur'an and Hadits, this boarding school continues to implement the teachings of the Thariqah 'Alawiyyah, especially through its daily majelis dzikr (religious gathering to remember Allah), and its weekly chanting of Maulid Simtud Durar (A Necklace of Pearls), written by the above-mentioned Habib 'Ali al-Habsyi. However, with the development of social media, some of these graduates have turned online in their dakwah. At the same time, with the more recent returns of the Indonesian $\mathrm{Ba}$ 'Alawi women from Hadhramaut, the preservation and transmission of the thariqah's teachings embraces wider audiences.

Ustadzah Halimah started her preaching through conventional media, namely books and offline religious gatherings. Her first book entitled Bidadari Bumi: 9 Kisah

\footnotetext{
${ }^{61}$ The increasing participation of the Ba 'Alawi women in public life can also be seen in the business and education sectors in different parts of Indonesia as well as in Hadhrami organizations. See: Slama, "Coming Down to the Shop', 313-33.
} 
Wanita Shalehah (Earthly Angels: Stories of Nine Pious Women), ${ }^{62}$ outlined stories of saintly women whom she met during her years in Tarim. She argued that these women did not live in heaven, but they were real and existed in our time. Through this book she emphasizes the importance of upholding and practicing good morality, which is the heart of the Thariqah 'Alawiyyah, as exemplified by those pious women. ${ }^{63}$

Her growing popularity and authority, especially as the student of Habib 'Umar b. Hafidz and Hababah Ummu Salim, has taken her to places such as Singapore, Malaysia, and Brunei Darussalam. In addition, she serves as a guide for pilgrimage tours to the Hadhramaut. ${ }^{64}$ She runs her own majelis taklim called Muslimah Al-Ikhwan in Jakarta as well as delivering some routine dakwah in various other locations. Ustadzah Halimah maintains her offline meetings in addition to her online endeavors, as this traditional form of learning helps sustain "an emotional bond between the self and the collectivity." ${ }^{65}$ The main sources for her teaching are classical texts including Al-Nasha'ih Al-Diniyyah wal Washaya Al-Imaniyyah (Religious Advice and Counsel of Faith) written by Habib 'Abdullah b. 'Alawi al-Haddad, and Al-Risalah Al-Jami'ah (Treatise of the Main Foundations of Religion) written by Habib Ahmad b. Zain al-Habsyi (d.1733), which clearly demonstrate the transmission of the teachings of the pious Ba 'Alawi ancestors to her congregation.

Her busiest time of the year appears to be in the month of Maulid, the time when Prophet Muhammad was born. The maulid celebration event, indeed, marks a crucial point in her dakwah as it is the moment when she holds a huge gathering. During the event, the audience chants shalawat (salutation to Prophet Muhammad), dzikr, and she typically underlines the importance of following in the footsteps of the Prophet as exemplified by the $\mathrm{Ba}$ 'Alawi ancestors. This endeavor of holding such mass gatherings creates the opportunity of articulating and transmitting the teachings of the thariqah, not only among the Ba 'Alawi women but also among a wider female Muslim audience.

In 2019, she held her maulid celebration event on December $1^{\text {st }}$. This date coincided with the $4^{\text {th }}$ Rabiul Tsani 1441, the month after Maulid. The reason given for not conducting the event during the month of Maulid was due to her busy schedule and some similar celebrations held by other Ba 'Alawi female pengajian in Jakarta, in which she

\footnotetext{
${ }^{62}$ This book was published by Wafa Production, and has been printed more than eight times. I am using the 2014 edition.

${ }^{63}$ Her other book Tutur Hati (Jakarta: Daarut Tauhid, 2013) consists of her posts on her Facebook wall between 2009 and 2012. The themes discussed include love for God, the importance of prayers, forgiveness, death and marriage relationships.

${ }^{64}$ Ismail Fajrie Alatas, "The poetics of pilgrimage: Assembling contemporary Indonesian pilgrimage to Hadramawt, Yemen," Comparative Studies in Society and History, 58, 3 (2016), 612-7.

${ }^{65}$ Bryan Turner, "Religious authority and the new media," Theory, Culture \& Society, 24, 2 (2007), 125.
} 
also took an active part. When I came to the event at 7 in the morning on that day, thousands of women had crowded the Balai Sudirman Convention Hall in Jakarta, where the maulid was conducted. According to one committee member, around 7,000 women attended the event. An important announcement was repeated several times that the audience was not allowed to record the event or take pictures because many of them were wearing full-face veils and took them off during the event. In addition to her preaching, the audience read Maulid Simtud Durar together. This reading shows how she tries to preserve the teaching and practice of the thariqah, which, as Ho argued in the context of maintaining the bond with the homeland, exist and endure "only so long as people continue to speak, sing, recite, read, write, narrate, and otherwise represent them."

In line with the development of social media, Ustadzah Halimah adapts her preaching strategies and uses these platforms, namely Facebook (@Halimah Alaydrus Page with 94,110 followers), Instagram (@halimahalaydrus with 251,000 followers, and @ muhasabahcintaevent with 25,600 followers), ${ }^{67}$ and a YouTube channel to convey her dakwah. While in her offline preaching she emphasizes some general religious messages, her online preaching is more up to date and includes messages on how to use social media wisely, issues within modern households, and relations between men and women in the digital era. In one Instagram video post, for example, she underlines the importance of avoiding riya' (showing off one's good deeds) on social media. ${ }^{68}$ She argued that social media is useful to share some good information but not to update one's status that shows one's participation in a religious event, as none of her social media posts contain pictures of her face or body.

In addition, she often shares quotes, which are very relevant to the needs of younger audiences. The quote below is one example:

Tetaplah jadi diri sendiri

Konsentrasilah terhadap perbaikan diri tanpa perlu menjadi orang lain

Maka seperti ulat, ia akan berubah menjadi kupu-kupu yang indah. ${ }^{69}$

\footnotetext{
${ }^{66}$ Ho, The Graves of Tarim, xxii.

${ }^{67}$ This data are recorded on 11 December 2020. Her personal Instagram account, for example, has an approximate addition of 2,000 followers per week.

${ }^{68}$ For a detailed account on how riya' became a topic in the era of social media among Muslims in Indonesia, see: Fatimah Husein and Martin Slama, "Online piety and its discontent: Revisiting Islamic anxieties on Indonesian social media," Indonesia and the Malay World, 46, 143 (2018), 80-93.

${ }^{69}$ IG posting, 21 June 2019.
} 
Be yourself

Be focused on self-improvement without needing to be somebody else

So like caterpillars, they will change into beautiful butterflies.

These types of postings are typically liked by thousands of followers and receive many comments. Ustadzah Halimah often replies to comments and questions. It is interesting to observe how she responds in a humble down to earth manner so as to make herself more accessible to wider and younger audiences. The example below exemplifies this style:

Linafakhrosa: Tapii aq pengeen jadii supiir ajaaah

Ustazah Halimah: @linafakhrosa ga sanggup gajinya. Supir import kaan...

Linafakhrosa: @halimahalaydrus asal dikasiih senyum ustadzah dah cukuup

Linafakhrosa: But I only want to be your driver

Ustadzah Halimah:@linafakhrosa I can't afford the salary. You're an imported driver, right?

Linafakhrosa: @halimahalaydrus if you gave me your smiles it is more than enough.

This style of communication does not discourage her from conveying the main teachings of the Thariqah 'Alawiyyah. Indeed, it is used to attract the younger Muslim generation to like her postings and to post comments, and therefore, when she conveys more serious dakwah messages, they would not resist. An example of her Instagram post shows a quote from her teacher Habib 'Umar b. Hafidz:

Jika besar tempat Allah dalam hatimu, maka akan tampak kecilah nilai selain Allah dalam pandanganmu. ${ }^{70}$

If Allah fully occupies your heart, others values than Allah will be small in your sight.

In the time of the Covid-19 pandemic in 2020, she also maximized the use of social media to conduct her yearly maulid celebration online by reading and discussing Maulid Simtud Durar in three separate live streaming events. With hundreds of thousands of online

\footnotetext{
703 February 2020.
} 
followers, Ustadzah Halimah's attempts at preserving and transmitting the teachings of the Thariqah 'Alawiyyah are gaining in significance. And in addition to her female audience these online platforms allow her to reach a male audience that otherwise would be harder to reach offline.

Ustadzah Khodijah offers a considerably different method in her dakwah as compared to Ustadzah Halimah. Her offline majelis taklim that she runs at her home focuses on reading the above-mentioned Ar-Risalah Al-Mu'awanah and Bidayah AlHidayah (The Beginning of Guidance) written by Imam al-Ghazali, which specifically expresses the teachings of the Thariqah 'Alawiyyah. In addition, she has been teaching at Madrasah Diniyyah Lilbanin Al-Khairiyah in Surabaya that is attended by (mostly) Ba 'Alawi, non-Ba 'Alawi Hadhramis and a limited number of local girls. This informal Islamic education that is attended by 170 students is held every afternoon and includes chanting of Simtud Durar Maulid and Qasidah Al-Burdah in ensuring that this tradition is preserved and transmitted to, especially, the $\mathrm{Ba}$ 'Alawi female children, but also to a wider audience. ${ }^{71}$

I joined an event that was organized by this madrasah on September $1^{\text {st }}, 2019$ at $A l$ Khairiyah Surabaya. This bi-annual event is called Adhwa' min Hayat Al-Musthafa (The Light of Prophet Muhammad's Life) and is exclusively for women and children. It was an event full of exhibitions, theatrical performances, and preaching on the life of the Prophet and his daughter Fatimah. It placed a strong emphasis on the importance of following the path of the Prophet and his family, as also exemplified by the Ba 'Alawi ancestors, not only for the $\mathrm{Ba}$ 'Alawi themselves but also for the wider public. The event was open for three days and we had to book our seat as it was in high demand, both in Ba 'Alawi circles and in the wider Surabayan Muslim communities. One committee member told me that this event was attended by hundreds of people. What is interesting is that most, if not all, of the students and teachers of this madrasah, including Ustadzah Khodijah, were wearing a full-face veil, imitating the clothing style of the Prophet's daughter that was displayed at the entrance of the event's door. Here the emphasis of following the exact deeds of the Prophet and his family members is very strong, which underlines the very teachings of the thariqah.

Similar to the scope and method that is applied by Ustadzah Khodijah, Ustadzah Syifa is concerned with the education of the young female generation of the $\mathrm{Ba}$ 'Alawi in the greater Solo area. In line with her offline method in dakwah, she focuses on teaching

\footnotetext{
${ }^{71}$ Interview with Ustadzah Khodijah in Surabaya, 16 November 2019.
} 
fiqh (Islamic law) at Diponegoro High School using Safinatun Naja' (Safety Vessel) written by Ahmad b. 'Umar asy-Syatiri (d. 1888), which was also used as a main reference at Dar al-Zahra when she studied there. She emphasized that what impressed her the most from her study at Dar al-Zahra was how the students "walk the talk." There were no bells ringing to remind the students of their responsibilities as all studies are conducted voluntarily. ${ }^{72}$ This is what she wants her students to imitate. She negotiates her dakwah strategies by not forcing her students to strictly follow what is prescribed in the Islamic law, but chooses the method of storytelling to follow the footsteps of the Prophet and his immediate families. We see here that the "canon of saints, texts, rituals, special places, and genealogies," which characterizes the central elements of the thariqah, is being retold and revived. ${ }^{73}$

Her passion for teaching was also channeled at Pesantren Darul Bathul AtThohiroh in Solo under the leadership of Ustadzah 'Alwiyah bt. 'Abdullah al-Junayd, a Ba 'Alawi woman born and raised in Hadhramaut, where she taught for one year (2013). The students of this female boarding school, which is named after the daughter of the Prophet Muhammad, Fathimah az-Zahra al-Bathul (the owner of pure character) ${ }^{74}$ are also mostly of $\mathrm{Ba}$ 'Alawi. This pesantren conducts monthly hadhrah, dzikr and tawassul (a prayer invoking deceased Ba 'Alawi ancestors). In addition, Ustadzah Syifa actively participates in weekly chanting of Hadhrah Basaudan, written by Syaikh 'Abdullah b. Ahmad Basaudan (d. 1850) and Habib 'Abdurrahman al-Masyhur (d. 1902), at her grandmother's house in Solo with some fifty Ba 'Alawi women. They start by reading Surah Yasin of the Qur'an, chant Asma'ul Husna (99 Names of Allah), and end with a question and answer time on a topic related to fiqh. Her active participation in the transmission of Prophetic knowledge and recitation of hadhrah prayers is clearly in line with the practices of the thariqah members.

This offline dakwah method is similar to that of Ustadzah Khodijah. Ustadzah Syifa's choice of focusing on the female students at Diponegoro School, where many Ba 'Alawi girls study, is based on her argument that their roles are central in preserving the teachings as prescribed by the Thariqah 'Alawiyyah and in transmitting them to the next generations, "These [Ba "Alawi] girls will later marry and raise their children and therefore it is important for them to understand the spiritual teachings as taught by our

\footnotetext{
${ }^{72}$ Interview with Ustadzah Syifa al-Haddad in Solo, 9 January 2020.

${ }^{73}$ Ho, The Graves of Tarim, 47.

${ }^{74}$ The term "bathul" is also usually translated as "chaste," Fatimah az-Zahra was relieved from menstruation by Allah in her entire life.
} 
grandfathers." 75 More importantly, the subject of fiqh that she is teaching forms the basis of the Islamic doctrines that these $\mathrm{Ba}$ 'Alawi girls should master and later practice in their life. She therefore attempts to transmit the study methods she gained in Tarim in the hope that the female students would not only implement Islamic law textually, but also love the teachings of Islam as practiced by their ancestors.

The impact of these attempts at preserving and transmitting the teachings of the Thariqah 'Alawiyyah is also felt by the wider Indonesian Muslim communities as practicing these teachings is not restricted to the Ba 'Alawis. Majelis Sahabat Cinta in Yogyakarta, which is very active online and offline, is a notable example. Established in 2014 as a learning community focusing on reading the Qur'an and performing Islamic worship, it regularly invites two $\mathrm{Ba}$ 'Alawi teachers to their gatherings, chiefly Ustadz Husein Nabil b. Najib Assegaf (b. 1970) and Ustadzah Halimah Alaydrus. However, since 2018 there has been a significant change within Majelis Sahabat Cinta's concerns as it inclines to invite more teachers of Hadhrami descent. It regularly conducts daurah, and maulid celebrations involving these Ba 'Alawi teachers including Ustadzah Muna alMunawwar, Ustadz Muhammad b. Husein al-Habsyi, Ustadz Musthofa Sayyidi Baragbah, and Ustadz Mahdi al-Kaff.

Among Majelis Sahabat Cinta's major gatherings, Kajian Bersama Majelis Muslimah Yogyakarta (Yogyakarta Female Muslim Joint Pengajian) held on March $12^{\text {th }}$, 2020 is worth discussing. They invited some major Ba 'Alawi female figures including the "trio Jindan" from Jakarta, referring to three daughters of the notable Habib Novel b. Salim Jindan (d. 2005), namely Ustadzah Amiroh Novel Jindan, Ustadzah Fatimah Novel Jindan and Ustadzah Fachriyah Novel Jindan. The event, held at Hotel Sahid Raya Yogyakarta, attracted around 1,000 participants, mostly non-Ba 'Alawi Muslim women. As in the case of the pengajian led by Ustadzah Halimah mentioned above, an important announcement was also repeated several times that the audience was not allowed to record the event or take pictures because some of them, including the three main speakers, are usually wearing full-face veils and took them off during the event.

The theme of this event was Perahu Cinta (the Vessel of Love) and was preceded by chanting shalawat and a video of Habib 'Umar b. Hafidz underlining the excellent morals of the descendants of the Prophet. The three teachers of the Jindan family preached the importance of implementing the good deeds prescribed by Allah and avoiding bad conduct. By listening to and learning from these three teachers, descendants of the Prophet

\footnotetext{
${ }^{75}$ Interview with Ustadzah Syifa al-Haddad in Solo, 9 January 2020.
} 
Muhammad, it is expected that the audience will join the "vessel of love" to come closer to the Prophet Muhammad and to take them to the final destination, Allah. All these activities reflect the important teachings of the Thariqah 'Alawiyyah.

The ethnographic accounts presented in this section reveal that there is a shifting role on the part of the Indonesian $\mathrm{Ba}$ 'Alawi women in preaching and transmitting the teachings of the thariqah. The new authority that the Ba 'Alawi women gained from studying in Tarim allows them to take an active role, beyond what their grandfathers would have thought. They make efforts to attend to the call of their teacher, Habib 'Umar b. Hafidz, that "Every student of Dar al-Zahra has to deliver their dakwah to the community so that those who are away from Allah could come closer to Him."76 Despite applying different methods, these three preachers show resemblances in their attempts to remind their audiences - Ba 'Alawi and other Muslims - of the importance of the teachings of the Thariqah 'Alawiyyah as exemplified by their ancestors, and to literally practice the teachings of the Prophet Muhammad and his family members.

\section{CONCLUSION}

This paper discussed the changing roles of $\mathrm{Ba}$ 'Alawi female preachers in preserving and transmitting the teaching of the Thariqah 'Alawiyyah in contemporary Indonesia. By focusing on these female scholars and religious leaders, it endeavors to foreground the less-heard voices of Hadhrami women from the Southeast Asian archipelago. Firstly, even though historically the men of the community were the main guardians and transmitters of the thariqah, I have described how Hadhrami women are now adopting this role as well. This is an important shift, especially within the Indonesian Hadhrami context, since the claim to public religious authority is not just left to the men, as it was historically, but now this exemplifies the Hadhrami women's contemporary "trajectories into Indonesian public realms." 77

Secondly, the authority they have gained from their studies in Tarim, whose curriculum places a heavy emphasis on tasawwuf, and their spiritual engagements with their teachers, notably Habib 'Umar b. Hafidz and Hababah Ummu Salim, have empowered them to be the preservers and transmitters of the teachings of the thariqah. While in the past they had a very limited access to religious knowledge and education and were able to only gain authority in private settings, they now contribute significantly to

\footnotetext{
${ }^{76}$ Interview with Ustadzah Syifa al-Haddad in Solo, 9 January 2020.

77 Slama, "“Coming Down to the Shop'," 313-33.
} 
the transmission of Islamic knowledge in general, and of Sufi knowledge and practices in particular, not only privately but also publicly. This has been strengthened with the call of Habib 'Umar b. Hafidz to spread the knowledge and practices they have gained from Dar al-Zahra, which could be seen as a continuous reminder to walk on this path.

Thirdly, these three $\mathrm{Ba}$ 'Alawi female preachers follow different strategies to convey their dakwah, but have the same goal on the preservation and transmission of the teachings of the thariqah, which are not restricted to the Ba 'Alawi, by underlining the importance of following the deeds of Prophet Muhammad and his family, and of pious Ba 'Alawi ancestors. Social media have certainly helped Ustadzah Halimah in conveying her message, but the choice of the other two female preachers of staying offline has also gained in significance as this caters to the needs of a different segment of the community. Their creative methods, including theatre performances and exhibitions, have proven capable of attracting a wider audience to learn the teachings of the thariqah. While the younger Indonesian male $\mathrm{Ba}$ 'Alawi preachers also use social media in their dakwah activities, the online activities of the female preachers cannot be overlooked. Ustadzah Halimah's social media accounts are as creative as men's accounts and have attracted a large audience to learn, understand, and practice the teachings of the thariqah. In addition, concerning offline preaching, $\mathrm{Ba}$ 'Alawi women enjoy greater benefits by being able to attend events with a predominantly male audience thanks to suitably segregated areas for women, whereas men cannot attend women-only events. This provides these women with more opportunities to learn, to transmit their knowledge, and to widen their networks.

To conclude, while some scholars have questioned the sustained Hadhrami diasporic identity in their host countries, my research shows that the Indonesian Ba 'Alawi female preachers play an active role in preserving and transmitting the teachings of the Thariqah 'Alawiyyah. Has this dynamic had an impact on the identity formation of Hadhramis in Indonesia by creating a strong sense of segregation from the local population, as I experienced during my childhood in Pasar Kliwon, Solo, narrated the beginning of this article? I argue otherwise, as these female Ba 'Alawi preachers are not uprooted from their localities and have, instead, successfully secured wide acceptance from the Indonesian Muslim community through their offline and online preaching activities. 